\title{
Hydroxymethylation of Methylpheophorbide a Exocyclic Ring
}

\author{
Dmitry V. Belykh, ${ }^{\mathrm{a}, \mathrm{b}}$ and Ekaterina V. Ashikhmina ${ }^{\mathrm{a}}$ \\ anstitute of Chemistry, Komi Scientific Centre of Ural Division of Russian Academy of Sciences, 167982 Syktyvkar, Russia \\ ${ }^{\mathrm{b} S y k t y v k a r}$ State University, 167001 Syktyvkar, Russia \\ ${ }^{\circledR}$ Corresponding authorE-mail: belykh-dv@mail.ru
}

The exocyclic ring of methylpheophorbide a was subjected to hydroxymethylation under Tollens reaction conditions. Some distinctions of the stereochemistry of this reaction were observed, compared to other condensation reactions involving this exocyclic ring.

Keywords: Methylpheophorbide $a$, hydroxymethylation, Tollens reaction.

\section{Гидроксиметилирование экзоцикла метилфеофорбида $a$}

\author{
А. В. Белых, \\ ${ }^{\mathrm{a}}$ Институт химии Коми НЦ УрО РАН, 167982 Сыктывкар, Россия \\ ${ }^{\mathrm{b}}$ Сыктывкарский государственный университет, 167001 Сыктывкар, Россия \\ @E-mail: belykh-dv@mail.ru
}

\begin{abstract}
Проведено гидроксиметилирование экзоичилла метилфеофорбида а в условиях реакции Толленса. Выявлены некоторые особенности стереохимии этой реакции по сравнению с другими конденсащиями с участием экзочикла метилфеофорбида а.
\end{abstract}

Ключевые слова: Метилфеофорбид $a$, гидроксиметилирование, реакция Толленса.

Development of efficient procedures for chemical modification of natural chorins (especially the most available chlorins of $a$-series) is of considerable importance, as these compounds are precursors for materials finding an increasing number of applications in medicine, ${ }^{[1-3]}$ catalysis, ${ }^{[4,5]}$ design of photonic polymers and nano-materials ${ }^{[-9]}$ and other areas of technology and science. The exocyclic ring of methylpheophorbide $a$ and its analogs can easily undergo enolization which provides its high reactivity. We had previously demonstrated $^{[10-13]}$ that this ring can act as a methylene component in Mannich reaction. In the current communication we report the results of further condensation studies of methylpheophorbide $a$ (1) and its analogs. Compound 1 reacted with formaldehyde at the presence of sodium carbonate in a water-benzene mixture (Tollens reaction). ${ }^{[14]}$ Such conditions appeared to be favorable for the formation of the corresponding hydroxymethyl derivative $\mathbf{2}$ (Scheme 1).

The structure of the obtained 13(2)-hydroxymethyl derivative was assessed by NMR, IR and electronic spectroscopy as well as by mass-spectrometry. ${ }^{[14]}$ The ${ }^{1} \mathrm{H}$ NMR spectrum of compound $\mathbf{2}$ contains a multiplet corresponding to the methylene protons of the substituent in position 13(2). The introduction of a second substituent in position 13(2) of the exocyclic ring is further confirmed by $5 \mathrm{~cm}^{-1}$ bathochromic shift of the ketone group in position 13(1).

In contrast to methylpheophorbide $a$ exocyclic ring Mannich aminomethylation, ${ }^{[10-13]}$ its hydroxymethylation is not diastereoselective, as a result both diastereomers are formed with a ratio close to 1:1 (according to ${ }^{1} \mathrm{H}$ NMR). The ${ }^{1} \mathrm{H}$ NMR spectra of the hydroxymethylation product 2 contains a double set of signals corresponding to the protons of two 13(2)-diastereomers. Due to almost equal chromatographic mobilities of the two diastereomers our attempts to separate them by column chromatography were not successful. The difference in the stereoselectivity of aminomethylation and hydroxymethylation reactions is probably due to the different size of electrophiles attacking the 


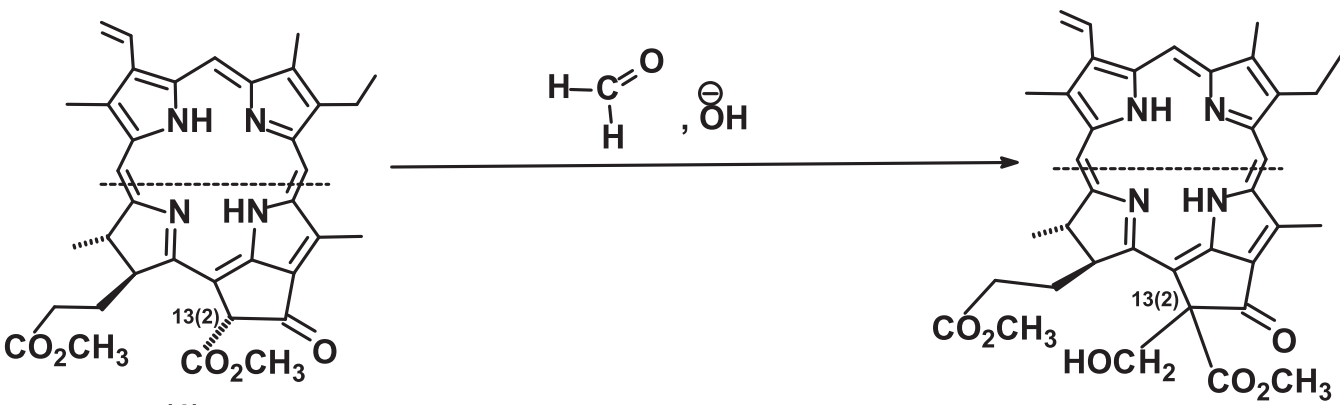

(1)

(2)

Paraformaldehyde, $\mathrm{Na}_{2} \mathrm{CO}_{3}, \mathrm{H}_{2} \mathrm{O}$-benzene, r.t., 1-3 h, $80 \%$ yield.

Scheme 1.

enolized exocyclic ring and it is not influenced by ionization of the enol. In Mannich reaction both non-ionized enol (when $\operatorname{bis}(\mathrm{N}, \mathrm{N}$-dimethylamino)methane is used) and enolate anion (in the classic variation) undergo an electrophilic attack (Scheme 2). The diastereoselectivity of this reaction can be explained assuming that both forms of the enolized methylpheophorbide $a$ exocyclic ring are not strictly planar due to mutual repulsion of substituents in positions 13(2) and 17. This results in one end of the double bond being more open for an attack by the electrophile than the other, thus only one diastereomer is formed. The molecule of formaldehyde is smaller than the amine molecules and the deformation of the exocyclic ring is not sufficient to direct the electrophilic attack to a certain position, resulting in an almost complete loss of stereoselectivity. Further decrease in stereoselectivity is presumably caused by the fact that it is the ionized enol form that is attacked. The +M-effect of the ionized hydroxyl group is much greater than that of the unionized, which might smoothen the exocyclic ring distortion and somewhat level the difference in the availability of different ends of the enol double bond for an electrophilic (Scheme 2).

Thus, we performed an original hydroxylmethylation of methylpheophorbide exo-cycle under Tollens reaction conditions and observed some distinctions of stereochemistry of this reaction compared to the other condensation reactions involving this cycle.

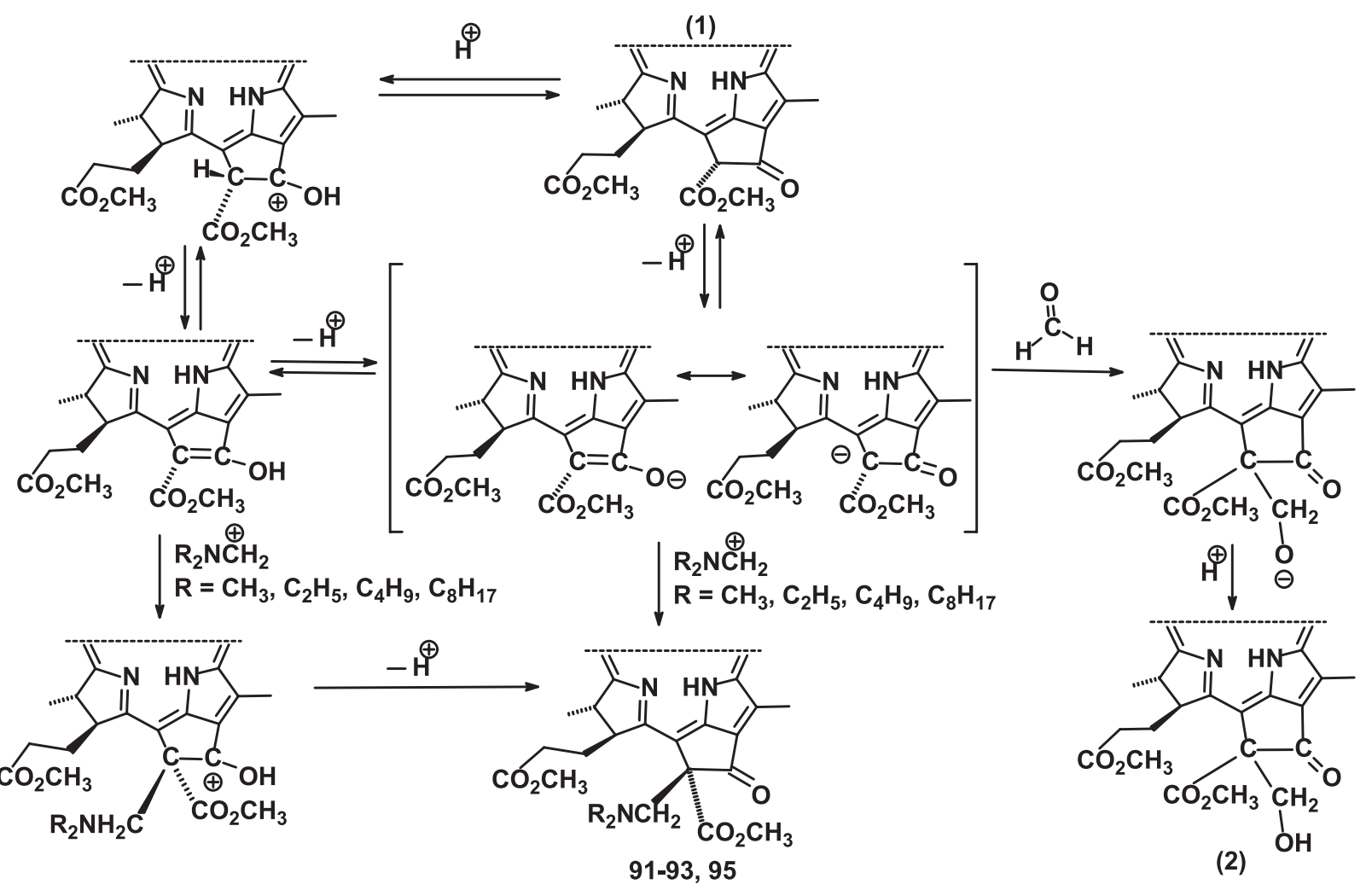

Scheme 2. 


\section{References and Notes}

1. Nyman E.S., Hynninen P.H. J. Photochem. Photobiol., B: Biology 2004, 73, 1-28.

2. DeRosa M.C., Crutchley R.J. Coord. Chem. Rev. 2001, 233234, 351-371.

3. Bregadze V.I., Sivaev I.B., Gabel D., Wöhrle D. J. Porphyrins Phthalocyanines 2001, 5, 767-781.

4. Tsujisho I., Toyoda M., Amao Y. Catal. Commun. 2006, 7, 173-176.

5. Gryglik D., Miller J.S., Ledakowicz S. Solar Energy 2004, 77, 615-623.

6. Amao Y., Komori T. Biosens. Bioelectron. 2004, 19, 843-847.

7. Amao Y., Komori T. Biosens. Bioelectron. 2007, 22, 15611565.

8. Alekseev A.S., Tkachenko N.V., Tauber A.Y., Hynninen P.H., Osterbacka R., Stubb H., Lemmetyinen H. Chem. Phys. 2002, 275, 243-251.

9. Tkachenko N.V., Hynninen P.H., Lemmetyinen H. Chem. Phys. Lett. 1996, 261, 234-240.

10. Belykh D.V., Tarabukina I.S., Gruzdev I.V., Kodess M.I., Kutchin A.V. J. Porphyrins Phthalocyanines 2009, 13, 949956.

11. Belykh D.V., Tarabukina I.S., Gruzdev I.V., Kuchin A.V. Russ. J. Org. Chem. 2009, 45, 452-459.

12. Belykh D.V., Nikiforov A.V. Macroheterocycles 2011, 4, 34-36.

13. Belykh D.V., Tarabukina I.S., Gruzdev I.V., Kutchin A.V. Mendeleev Commun. 2007, 17, 340-342.

14. Methylpheophorbide $a(50 \mathrm{mg}, 0.082 \mathrm{mmol})$ was dissolved in $20 \mathrm{ml}$ of benzene, then $50 \mathrm{mg}$ paraformaldehyde (equal to $1.7 \mathrm{mmol}$ of formaldehyde) and $50 \mathrm{mg}(0.472 \mathrm{mmol})$ of $\mathrm{Na}_{2} \mathrm{CO}_{3}$, in $0.5 \mathrm{ml}$ of water were introduced. The reaction mixture was stirred for $1 \mathrm{~h}$, then extracted with chloroform $(100 \mathrm{ml})$ and washed thoroughly with water to remove residual paraformaldehyde and $\mathrm{Na}_{2} \mathrm{CO}_{3}$. The resulting extract was dried with anhydrous sodium sulfate and evaporated at 40-50 ${ }^{\circ} \mathrm{C}$ under reduced pressure. The hydroxymethylation product was isolated by column chromatography on silica (eluting with $\mathrm{CCl}_{4}$-acetone 40:1). The collected fractions were monitored by TLC (Sorbfil, $\mathrm{CCl}_{4}$-acetone 4:1). The fractions containing the main reaction product were evaporated on a rotary evaporator. The product yield was $42 \mathrm{mg}(80 \%)$. MALDI $(\mathrm{m} / \mathrm{z}): 637.25\left(\mathrm{MH}^{+}\right)$(for $\mathrm{MH}^{+}\left(\mathrm{C}_{37} \mathrm{H}_{41} \mathrm{~N}_{4} \mathrm{O}_{6}\right)$ calculated 637.30). IR (KBr) cm ${ }^{-1}: 1610$ ("chlorin band"), 1732 ( $v \mathrm{C}=\mathrm{O}$ ester), 1695 ( $\mathrm{vC}=\mathrm{O}$ exocyclic ring ketone group). $\mathrm{UV}-\mathrm{Vis}\left(\mathrm{CHCl}_{3}\right) \lambda \mathrm{nm}$ (relative intensity, \%): 668(44), 610(5), 541(14), 514(15), 416 (100) (Soret band). ${ }^{1} \mathrm{H} \mathrm{NMR}\left(\mathrm{CDCl}_{3}, 300 \mathrm{MHz}\right) \delta \mathrm{ppm}(\mathrm{J} / \mathrm{Hz}$, signals of different diastereomers are separated with a dash): $-1.40 /-1.28$ (1H, wid.s., NH-III); 0.50/0.64 (1H, wid.s., NH-I); $18-\mathrm{CHCH}_{3}: 1.56(3 \mathrm{H}, \mathrm{d}, J=7.3 \mathrm{~Hz}) / 1.71(3 \mathrm{H}, \mathrm{m}) ; 1.54-1.56$ $\left(3 \mathrm{H}, \mathrm{m}, 8-\mathrm{CH}_{2} \mathrm{CH}_{3}\right) ; 2.09-2.60\left[4 \mathrm{H}, \mathrm{m}, 17-\mathrm{CH}_{2} \mathrm{CH}_{2} \mathrm{COOCH}_{3}\right]$; $3.24 / 3.25\left(3 \mathrm{H}, \mathrm{s}, 7-\mathrm{CH}_{3}\right) ; 3.41 / 3.42\left(3 \mathrm{H}, \mathrm{s}, 2-\mathrm{CH}_{3}\right) ; 3.52 / 3.55$ $\left(3 \mathrm{H}, \mathrm{s}, \mathrm{CH}_{2} \mathrm{CH}_{2} \mathrm{COOCH}_{3}-17\right) ; 3.71\left(3 \mathrm{H}, \mathrm{s} 12-\mathrm{CH}_{3}\right) ; 3.62 / 3.72$ $\left(3 \mathrm{H}, \mathrm{s}, 13(2)-\mathrm{CO}_{2} \mathrm{CH}_{3}\right) ; 3.69-3.73\left(2 \mathrm{H}, \mathrm{m}, 8-\mathrm{CH}_{2} \mathrm{CH}_{3}\right) ; 4.25-$ $4.52(2 \mathrm{H}, \mathrm{m}, 17-\mathrm{H}, 18-\mathrm{H})$; 4.87-5.30 (2H, m, 13(2)- $\left.\mathrm{CH}_{2} \mathrm{OH}\right)$; $3-\mathrm{CH}=\mathrm{CH}_{\text {cis }}: 6.20(1 \mathrm{H}, \mathrm{d}, J=11.2 \mathrm{~Hz}) ; 3-\mathrm{CH}=\mathrm{CH} H_{\text {trans }}: 6.31$ $\left.\left(1 \mathrm{H}, \mathrm{d}, \mathrm{CH}=\mathrm{CH} H_{\text {trans }}, J=17.3 \mathrm{~Hz}\right]\right) ; 3-\mathrm{CH}=\mathrm{CH}_{2}: 7.97(1 \mathrm{H}$, $\mathrm{m}) ; 8.51 / 8.55(1 \mathrm{H}, \mathrm{s}, \mathrm{H}-20)$; 9.35/9.38 $(1 \mathrm{H}, \mathrm{s}, \mathrm{H}-5)$; 9.52/9.54 $(1 \mathrm{H}, \mathrm{s}, \mathrm{H}-10)$. The IR spectra were recorded on a Shimadzu IR Prestige 21 Fourier-spectrometer in $\mathrm{KBr}$ discs. The UVVis spectra were obtained on a Shimadzu UV-1700 in $10 \mathrm{~mm}$ quartz cells (dichloromethane was used as a blank sample). The ${ }^{1} \mathrm{H}$ NMR spectra of were recorded in $\mathrm{CDCl}_{3}$ on a Bruker Avance II instrument ( 300 and $75 \mathrm{MHz}$ ). The MALDI mass spectra were obtained on a Bruker Ultraflex TOF/TOF using dihydroxybenzoic acid matrix. The reaction completion was monitored by TLC on Sorbfil plates. Silica gel 60 (0.060-0.200 $\mathrm{mm}, 70-230 \mathrm{mesh}$ ) was used for column chromatography. 